\title{
Molecular diagnosis of pathogenic and opportunistic pathogenic bacteria in populations of valuable kinds of fishes
}

Yu. Rud,

L. Dragan,

P. Tsapenko,

I. Hrytsyniak

L. Buchatskii,

The purpose. To study molecular-biological features of causal organisms of contagions of fishes of bacterial etiology. Methods. Microbiological, molecular-biological, icthyological. Results. Complex analysis is carried out, and series of conditional-pathogenic and pathogenic bacteria is determined in populations of rainbow trout, sterlet, European catfish, and carp, cultivated in Ukraine. Analysis of a gene $16 \mathrm{~S}$ rRNK of these bacteria is carried out. Conclusions. Methods of identification are elaborated of conditional-pathogenic and pathogenic bacteria on the basis of polymerase chain reaction.

Key words: molecular diagnosis, polymerase chain reaction, bacterial diseases of fishes.

Introduction. According to the International Office of Epizootics (OIE), infectious diseases in fish farming cause annual losses of $10-15 \%$ of the total production costs. Therefore, diagnosis of fish pathogens is a burning issue for modern aquaculture and can guarantee effective prevention and also success in the treatment of infectious diseases [1].

The use of DNA technology aimed to the direct identification of the genetic material of pathogens of various etiologies is gradually replacing the labor-intensive cultures, serologic and histological diagnostic methods. Infectious diseases of fish such as furunculosis (Aeromonas salmonicida), enteric redmouth diseases (Yersinia ruckeri), bacterial hemorrhagic septicemia (Aeromonas hydrophila), bacterial kidney disease (Renibacterium salmoninarum), columnaris disease (Flavobacterium columnarae), bacterial septicemia of the catfish (Edwardsiella ictaluri), pseudomonosis Pseudomonas sp., and cold water disease (BCWD) (Flavobacterium psychrophila) are widespread throughout the world and lead to significant economic losses in aquaculture [2]. Therefore, the detection of pathogenic microorganisms in fish populations is an important step towards the prevention of infectious diseases [3].

Traditionally, the diagnosis of bacterial diseases was carried out using bacteriological methods using nutrient media, followed by identification of the phenotypic properties of investigated strains. But these methods are labor-intensive, have low-sensitivity and always require a previous pathogen isolation. The methods of polymerase chain reaction (PCR) and restriction analysis of amplified products (restriction fragment length polymorphism, RFLP) of the 16S rRNA gene allow to identify these microorganisms to the genus, and in some cases to the species. In addition, this PCR-RFLP assay reduces the cost of reagents for reactions and saves time for identification of each bacteria [4].

The purpose of research. To study the molecular-biological properties and phylogenetic affinity of bacterial pathogens of cultured fish species and based on genetic data to develop methods for its rapid identification. 
Materials and methods. Investigation of opportunistic and pathogenic bacteria was conducted in populations of rainbow trout Oncorhyncus mykiss (Chernivtsi region), sterlet Acipencer ruthenus (Kyiv region), European catfish Silurus glanis (Dnipropetrovsk region) and common carp Cyprinus carpio (Donetsk region). The primary culture of microorganisms from the pathological material was estimated on the nutrient medium of the TSA. For bacteriological analysis, the samples of abdominal cavity of experimental fish were used. The study of the morphology of colonies and cells, as well as the isolation of pure culture, was carried out according to generally accepted methods [5].

For molecular-biological studies, DNA was purified from samples taken directly from the diseased fish. Also, DNA was extracted from bacterial suspensions obtained from individual colonies of pure cultures. GeneJet DNA Purification Kit (ThermoScientific) was used to extract DNA. The DNA was dissolved in deionized water free of nucleases [6].

Vector NTI 11 was used to develop primers and to determine their specificity and physical properties. In addition, the specificity of the primers was verified using the online service BLAST (www.ncbi.nim.nih.gov/blast). The amplification was carried out on a thermocycler 96 Universal Gradient PEQ STAR (PEQLAB, Germany). The results of electrophoresis were observed under ultraviolet transilluminator [7]. Restriction endonucleases Aval, BamHI, EcoRI, Pstl, Smal were used for restriction analysis.

Determination of the nucleotide sequences. The extraction of DNA from the gel was carried out using a set of Silica Bead DNA Gel Extraction Kit (Fermentas) according to the manufacturer's protocol. DNA nucleotide sequences were investigated using an automatic DNA sequencer "Genetic Analyzer 3130" (Applied Biosystems, USA) using a sequencing kit (BigDye ${ }^{\circledR}$ Terminator v3.1 Cycle Sequencing Kit). Alignment of DNA nucleotide sequences was performed using ClustalW algorithms in the MEGA version 6.0 and BLASTN software. For comparison of DNA sequences of isolated pathogenic and opportunistic bacteria, the data from the database of the National Center for Biotechnology Information (NCBI, USA) was used.

Results. In order to avoid excessive microbiological load, in our experiment, we did not conduct bacteriological asay from the skin and gills as the microbiota from these surfaces is mostly dependent on microbiota of water. The absence of pathogenic and opportunistic bacteria in the abdominal cavity is a sign of the integrity of homeostasis and clinically healthy fish. As the results of our microbiological tests, 26 strains of microorganisms were isolated on dense nutrient media from samples of internal organs of clinically healthy and diseased species of rainbow trout, sterlet, European catfish and common carp. After primary investigation, the allocation of pure cultures and microscopic analysis of isolated strains, all bacteria were classified into 4 genera and one family. Another 7 strains of bacteria were noted as unclassified, since the morphological and phenotypic characteristics did not give a clear distinction in their identification. Thus, on the basis of bacteriology, members of the genera Aeromonas, Flavobacterium, Pseudomonas, Vibrio and Enterobacteriaceae family were identified.

Our results in molecular biology studies showed that oligonucleotide primers specific to the 16S rRNA gene fragment were selected properly. All strains of isolated pathogenic and opportunistic bacteria were taken for PCR assay. For comparison of sensitivity for both molecular and bacteriological assays, all bacteria strains were cultivated in a pure culture throughout the whole experiment. As expected all PCR products were in size of $950 \mathrm{bp}$ (figure). 


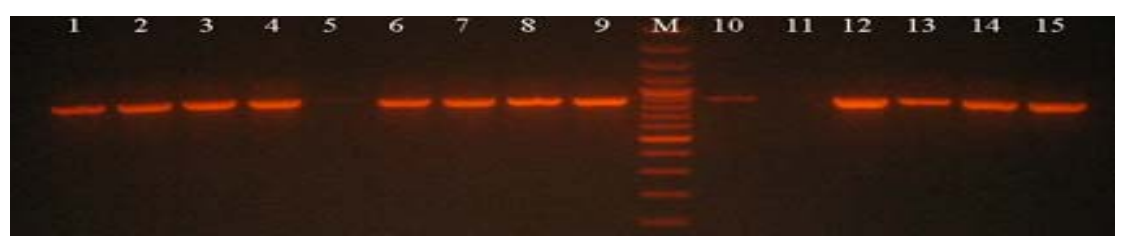

Figure. Amplification of 16S rRNA gene fragments of bacteria isolated from Cyprinus carpio (1-4), Acipencer ruthenus (5-8), Silurus glanis (9-11) and Oncorhyncus mykiss (12-15); M - 100 bp DNA marker (ThermoScientific)

Agarose gel electrophoresis of PCR products of 16S rRNA gene fragments of isolated bacteria after RFLP showed a difference in the number of restriction fragments for nine types of bacteria and a group of bacteria from the Enterobacteriaceae family. For enterobacteria species the sites for restriction enzymes of Aval, EcoRI and Smal were identified. Only two sites for EcoRI restriction enzymes were characteristic for another member of the Enterobacteriaceae family, bacteria Yersinia $s p$. The results of restriction fragment analysis identified such members of Enterobacteriaceae family as Citrobacter freundii (carp), Edwardsiella ictaluri and E. tarda (catfish) and Yersinia sp. (trout). Recently, the number of enterobacteria isolated from clinically diseased fish is constantly increasing. The main reason for this phenomenon is pollution of water. Given the significant level of variability of phenotypic signs of enterobacteria and their resistance to antibiotics, this kind of opportunistic pathogens are characterized by high infectivity and virulence for many fish species.

The sites for restriction enzymes Aval, EcoRI, Pstl and Smal were presented in Aeromonas strains. It should be emphasized that all members of the genus Aeromonas are pathogenic and conditionally pathogenic for several fish species. Thus, Aeromonas caviae causes an infectious disease in sterlet. A. hydrophila is the causative agent of bacterial septicemia in carp and sterlet. A. salmonicida causes furunculosis in salmon species. An additional set of restriction enzymes or specific oligonucleotide primers should be used for their rapid differentiation. Also, these strains of bacteria can be diagnosed using classical bacteriological and biochemical assays, but these are long-term methods.

Shewanella sp. was identified through the sites for Aval, Pstl, Aval and EcoRI respectively (Table). P. fluorescens was identified using sites of restriction for Aval and Smal. The member of the genus Vibrionaceae, the bacteria Vibrio salmonicida contained restriction fragments EcoRI and Smal.

For identification of Flavobacterium species, that are pathogenic bacteria for salmonids, only one enzyme was used. Unlike other groups of bacteria, the Flavobacterium sp. contain only the $\mathrm{BamHI}$ restriction site, which is specific for the Flavobacterium columnare. Another member of the genus, F. psychrophilum, has not any restriction sites in the fragment of the 16S rRNA gene in general. Another members of the opportunistic microbiota of salmonids, the bacteria Flexibacter sp., which previously belonged to the genus Flavobacterium, was characterized by a unique HindlII site and easily identified among all other types of bacteria (table).

Table. Restriction sites for 16S rRNA gene fragments of pathogenic and opportunistic bacteria in populations of Cyprinus carpio, Acipencer ruthenus, Oncorhyncus mykiss and Silurus glanis

\begin{tabular}{|l|l|c|}
\hline Bacteria & Restriction sites of 16S rDNA gene & Fish \\
\hline Aeromonas caviae & Smal (328-333), EcoRI (390-395), Pstl (724-729) & Sterlet \\
\hline A. hydrophila & Smal (328-333), EcoRI (390-395), Pstl (724-729) & Carp, Sterlet \\
\hline
\end{tabular}




\begin{tabular}{|l|l|c|}
\hline A. salmonicida & Smal (328-333), EcoRI (390-395), Pstl (724-729) & Trout \\
\hline Citrobacter freundii & Smal (328-333), EcoRI (390-395) & Carp \\
\hline Edwardsiella ictaluri & Smal (328-333), EcoRI (390-395) & Catfish \\
\hline E. tarda & Smal (328-333), EcoRI (390-395) & Catfish \\
\hline $\begin{array}{l}\text { Flavobacterium } \\
\text { columnare }\end{array}$ & BamHI (64-69) & Trout \\
\hline F. psychrophilum & N/A & Trout \\
\hline Flexibacter sp. & HindllI (171-176) & Trout \\
\hline $\begin{array}{l}\text { Pseudomonas } \\
\text { fluorescens }\end{array}$ & Smal (328-333), Aval (327-332) & Carp \\
\hline Shewanella sp. & Aval (328-333), EcoRI (390-395) & Sterlet \\
\hline Vibrio salmonicida & Smal (327-332), EcoRI (719-724) & Trout \\
\hline Yersinia sp. & EcoRI (390-395, 719-724) & Trout b \\
\hline
\end{tabular}

${ }^{*}$ Primer specificity and sequence of $16 \mathrm{~S}$ rRNA bacterial genes were tested using the online BLAST service (www.ncbi.nim.nih.gov/blast).

** When creating degenerative primers, attention was paid to the 3 '-end.

Thus, the diagnosis and identification of bacterial and viral pathogens in fish can be accelerated from several days to one working day, when clinical samples are tested directly [8]. Other agents of infectious diseases, which are difficult or impossible to identify by culture methods, often remain undetected, so the use of PCR is the only alternative tool to demonstrate their presence in the pathological material [9].

Our results showed that universal oligonucleotide primers, specific for the 16S rRNA gene of bacteria, amplified a DNA fragments. Using RFLP and such enzymes as Aval, BamHI, EcoRI, Pstl, and Smal vast majority of pathogenic and opportunistic bacteria can be identified to the genus or even the species.

Protection of cultured fish species from bacterial infections is an actual problem in sustainable aquaculture [10]. Despite some progress have been achieved in recent years in development of measures for the prevention and treatment of fish infectious diseases, bacterial diseases remain quite widespread and cause significant economic losses to fish farms [11].

Pathogenic bacteria are economically important infectious agents that cause high mortality in cultured fish species. Despite the high significance of these pathogens, for today there is insufficient information about the mechanisms of the pathological process, transmission, port of infection, spread through organism, virulence factors and the host's immune response. For effectively combat bacterial diseases, more experimental data on the immunogenicity of pathogens are needed. Therefore prevention of the disease, which includes rapid diagnosis, is the only affordable and actual way to fight bacterial infections in sustainable aquaculture.

\section{Conclusions}

The bacteria from the Enterobacteriaceae family, species of the genus Flavobacterium, bacteria strains of Yersinia sp., Vibrio salmonicida, Aeromonas sp. were identified in rainbow trout. It is indicating a significant bacterial load and the risk of an infectious disease caused by these bacteria species.

The strains of Aeromonas caviae, A. hydrophila, Shewanella sp. were identified in sterlet. It was established that the most dangerous bacterial disease in sturgeon aquaculture may be bacterial septicemia, caused by bacteria A. hydrophila. 
We identified bacteria $A$. hydrophila and $A$. sobria in common carp. These strains are the most dangerous pathogens in carp aquaculture and can lead to significant losses, as well as bacteria $P$. fluorescens and opportunistic bacteria Acinetobacter $s p$.

Thus, a complex method of PCR-RFLP of $16 \mathrm{~S}$ rRNA gene for the identification of the most common bacteria - agents of infectious diseases of fish was developed and tested. The proposed method is more precise, easy to use and economical compared to traditional bacteriological assays and allows identification of bacterial pathogens within one day.

\section{Bibliography}

1. Woo P.T.K. Fish Diseases and Disorders. Volume 3: Viral, Bacterial and Fungal Infections / P.T.K. Woo, D.W. Bruno. - 2011. CABI, 944 pp.

2. Cunningam C.O. Molecular diagnosis of fish and shellfish disease: present status and potential use in disease control // Aquaculture. - 2002. - Vol. 206. - P. 19-55.

3. Zaloilo O.V., Rud Yu.P., Zaloilo I.A., Grytsyniak I.I. The modern methods of diagnosis in fish diseases (review) // Fisheries science of Ukraine. - 2016. - № 2. - P. 48-64.

4. Altinok I., Kurt I. Molecular diagnosis of fish diseases: a review // Turkish Journal of Fisheries and Aquatic Sciences. - 2003. - Vol. 3. - P. 131-138.

5. 5. Musselius V.A., Vanyatinskiy V.F., Vikhman A.A. i dr. // Laboratornyy praktikum po boleznyam rib. - M.: Legkaya i pishchevaya prom-st', 1983. - $296 \mathrm{~s}$.

6. Sambrook J., Russell D.W. Molecular cloning: a laboratory manual, 3rd ed. - New York: Cold Spring Harbour, 2001.

7. McPherson M.J., Moller S.G. PCR. The basics: from background to bench. - New York: BIOS Scientific Publishers Ltd, 2000. - p. 276.

8. Rud Yu.P. Rapid diagnostic of fish flavobacterium by the method of polymerase chain reaction // Agricultural microbiology. - 2013. - Vol. 18. - P. 132-145.

9. Mata A.I., Gibello A., Casamayor A. Multiplex PCR assay for detection of bacterial pathogens associated with warm-water streptococcosis in fish // App. Environ. Microbiol. 2004. - Vol. 70. - P. 3183-3187.

10. Rud Yu.P., Buchatskiy L.P. Molecular diagnosis of fish infectious diseases // Animal breeding of Ukraine. - 2016. - № 4-5. - C. 28-31.

11. Vovk N.I. Ichthyopathological studies - an important component of biomonitoring of water bodies // Fisheries science of Ukraine. - 2009. - № 3. - P. 106-109. 